\title{
Mollusk Species Richness on the Rocky Shores of the State of Guerrero, Mexico, as Affected by Rains and Their Geographical Distribution
}

\author{
Flores-Rodríguez Pedro ${ }^{1}$, Flores-Garza Rafael ${ }^{1}$, García-Ibáñez Sergio ${ }^{1}$, Valdés-González Arcadio ${ }^{2}$, \\ Violante-González Juan ${ }^{1}$, Santiago Cortés Enedina ${ }^{1}$, Galeana-Rebolledo Lizeth ${ }^{1}$, \\ Torreblanca-Ramírez Carmina ${ }^{1}$ \\ ${ }^{1}$ Unidad Académica de Ecología Marina, Universidad Autónoma de Guerrero, Acapulco, México; ${ }^{2}$ Universidad Autónoma de Nuevo \\ León, Laboratorio de Acuacultura, Facultad de Ciencias Biológicas, Ciudad Universitaria, San Nicolás de los Garza, México. \\ Email: pfloresrodriguez@yahoo.com
}

Received August $18^{\text {th }}, 2012$; revised September $26^{\text {th }}, 2012$; accepted October $11^{\text {th }}, 2012$

\begin{abstract}
Natural processes in ecosystems shows significant variations in species richness with regular cycles that can be altered by natural or anthropogenic activities; the present research was in order to understand on some of these variations. The objectives were: 1) determine the species richness of rocky intertidal mollusks; 2) track their geographical distribution at State level; and 3) determine the changes in species richness as a result of rainfall on an annual cycle. For these purposes it was sampled in March, June, September and December 2005, the sampled area was $20 \mathrm{~m}^{2}$ for each collecting site; the sampling unit was a PVC rectangle frame one by two meter per side. The mollusks found within the sampling units were collected, identified and counted. The species distribution was analyzed by sites and regions, considered species richness per season, and the distributional patterns by rainy season historical records. A total of 62 mollusks species were found, its richness associated with substrate stability and wave intensity on each site, Gastropods had the highest species richness. When analyzing the regional distribution and sites, it was found a pattern of species richness roughly constant in the proportion of species with wide distribution (generalists) versus those of restricted spatial representation (specialists). Gastropods had the highest number of species with restricted spatial representation. Seasonal rainfall differences did not quantitatively altered on the overall the species of mollusks in the rocky intertidal sampled zone however, in the analysis per Class, Gastropoda indicated changes in species richness influenced by rainfall, which were not observed in Bivalvia and Polyplacophora, suggesting that those changes might depend on adaptive processes or the lack of adaptation of gastropod species to the characteristics of the rocky intertidal habitat.
\end{abstract}

Keywords: Rocky Shore; Species Richness; Geographic Distribution; Rain Effects; Mollusks

\section{Introduction}

The State of Guerrero has a humid tropical climate with different types of rocky substrates that occur along the coasts, causing great species richness, which can be affected by changes in the amount of rainfall during the year. Species richness shows significant variations that conform to natural processes in ecosystems, and its cycles can be altered by natural or anthropogenic activities such as pollution, overexploitation of habitat, and introduction of exotic species, which among other things are considered as the main forces leading to changes in species richness and community structure [1]. In nature the dispersion can be influenced by many factors, including intrinsic characteristics of some species (e.g. mobility, specificity for different resources or abilities to perceive the quality, size or structure of the parcels they inhabit) and/or characteristics of the habitat itself [2]. Identifying changes in diversity, either in the number of species, abundance, distribution, or dominance, can alert us of detrimental processes [3]. There are several reports in the literature on rocky coast mollusks for different parts of the Americas, which analyzes the relationship between species richness, wave intensity and type of substrate [4-8]. Regarding the Mexican Pacific coasts there have also been studies on this subject [9-12]. From the reports in the literature on species richness associated with rocky substrate in the State of Guerrero, most of them were made on Acapulco [13-21]; literature reports are scarce for other places along its coasts [22-24]. The aforementioned reports analyzed the species richness locally, their vertical distribution in the intertidal zone, and ecological 
features, but do not cover the geographical distribution of species, nor changes in species richness caused by rains, nor do they include temporary component analysis. In the State of Guerrero the need has been recognized to expand the level of understanding and knowledge about marine mollusk fauna and because of it, the scope of this research were: 1) determine the species richness of rocky intertidal mollusks; 2) track their geographical distribution at State level; and 3) determine the changes in species richness as a result of rainfall on an annual cycle.

\section{Materials and Methods}

\subsection{Study Area}

The coastline of the State of Guerrero is located in the Mexican Tropical Pacific (Figure 1); The coastline of the State of Guerrero is located in the Mexican Tropical Pacific (Figure 1); the climate is warm, sub-humid year round with considerable summer rains (Aw type) and has low winter rains, rating $5 \%$ to $10 \%$ of the total yearly rain fall. The coast has an approximate length of $470 \mathrm{~km}$, and according to regional characteristics it is located in the morphotectonic unit number VIII in front of which is a very narrow continental shelf. The coastline is parallel to the Mesoamerican Mexican pit. It is classified as conti- nental collision coast, dominated by primary coasts formed by diastrophic movements, with faults and fault scarps. However there are secondary coasts, to a lesser extent formed by erosion of waves, coastal headlands and wavecut terraces; and higher secondary coasts of marine deposition, and barrier beaches and hooks [25]. The surface water temperature on an annual cycle fluctuates between $26^{\circ} \mathrm{C}$ and $28^{\circ} \mathrm{C}$, the semidiurnal tides are mixed and show a variation of $\pm 1 \mathrm{~m}$ [26]. The average sea level has a seasonal variation with a decline between December and May, and a rise from June to November [27]. Significant rains occur during the summer, hurricane season officially runs from May 15, when the start of the rainy season, to November 30th when the end of the rainy season [28]. For this work, nine sites with rocky coast considered as representative of different types of substrates and distributed in the three coastal regions of Guerrero were selected; collecting sites were: in the Costa Chica region were three locations: Punta Maldonado, Las Peñitas, and Playa Ventura; in the Acapulco region there are two locations: Zoológico at Isla La Roqueta, and Palmitas at Isla La Roqueta, and for the Costa Grande region there were four locations: Piedra de Tlacoyunque, Barra de Potosi Expuesto, Barra de Potosi Protegido, and Playa Troncones (Table 1).

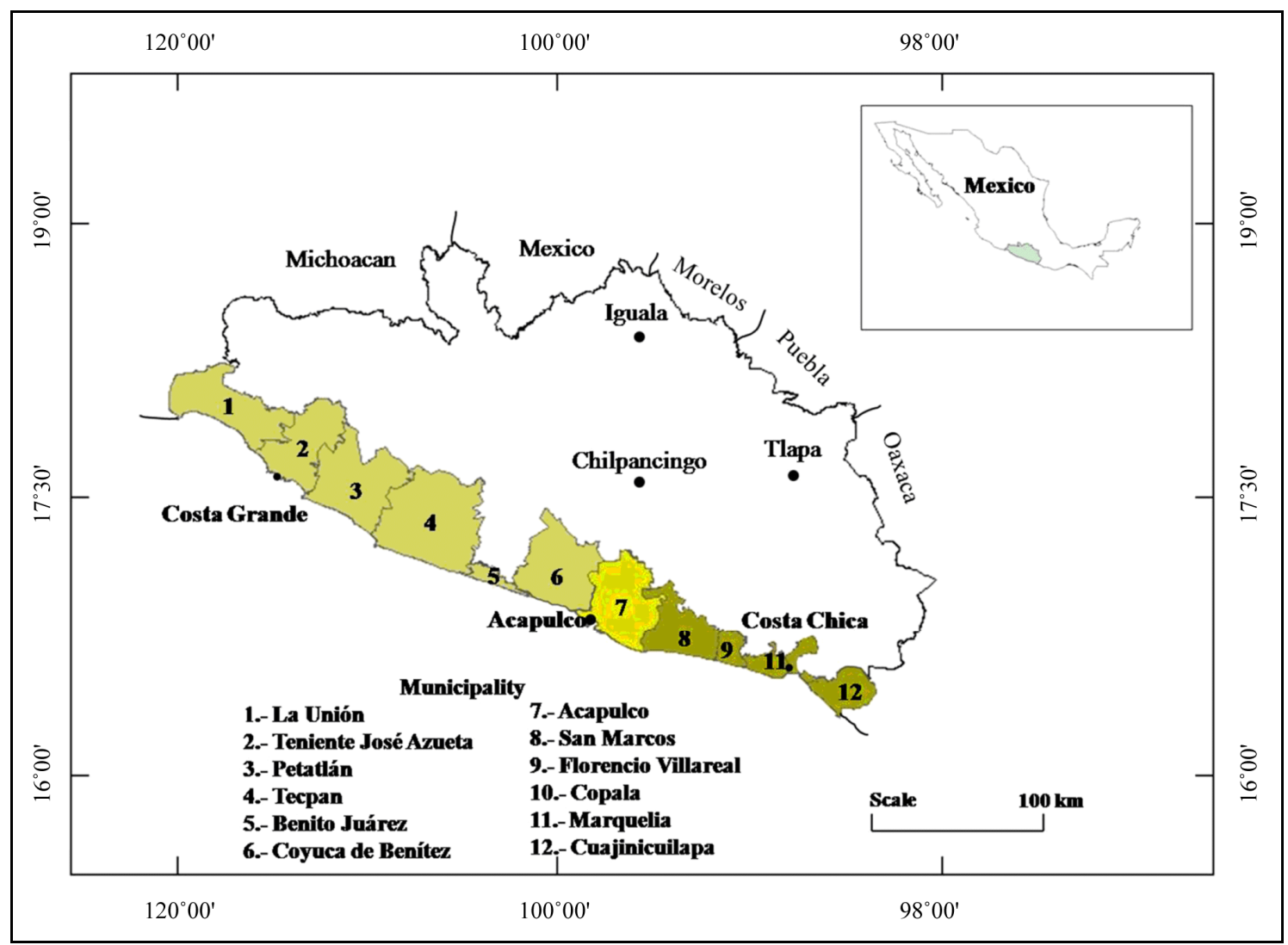

Figure 1. Map of the coast of Guerrero, Mexico. 
Table 1. Description of sampling sites and substrate types.

\begin{tabular}{|c|c|c|c|c|}
\hline Sites & Coodrenates & MPIO & Sustrate description & W.I. \\
\hline \multicolumn{5}{|c|}{ Region costa Chica } \\
\hline $\begin{array}{l}\text { Punta } \\
\text { Maldonado }\end{array}$ & $\begin{array}{l}16^{\circ} 19^{\prime} 35,49^{\prime \prime} \mathrm{N} \\
98^{\circ} 34^{\prime} 12,65^{\prime \prime} \mathrm{W}\end{array}$ & Cuajinicuilapa & $\begin{array}{l}\text { Sedimentary Rocks sandstone type. Fragile substrate, has many } \\
\text { cavities of varying diameter and depth, widely distributed }\end{array}$ & High \\
\hline Las Peñitas & $\begin{array}{l}16^{\circ} 33^{\prime} 14,4^{\prime \prime} \mathrm{N} \\
98^{\circ} 46^{\prime} 22,0^{\prime \prime} \mathrm{W}\end{array}$ & Marquelia & $\begin{array}{l}\text { Metamorphic rocks gneiss type. Wave resistant, stable fixed substrate, } \\
\text { rough surface made of protrusions, cracks and crevices. }\end{array}$ & Media \\
\hline \multicolumn{5}{|c|}{ Region acapulco } \\
\hline Zoológico & $\begin{array}{l}16^{\circ} 49^{\prime} 11,2^{\prime \prime} \mathrm{N} \\
99^{\circ} 54^{\prime} 88,8^{\prime \prime} \mathrm{W}\end{array}$ & Acapulco & $\begin{array}{l}\text { Igneous rocks of varying size, fixed substrate, semi rough with many } \\
\text { cracks, crevices and holes. }\end{array}$ & High \\
\hline Palmitas & $\begin{array}{l}16^{\circ} 49^{\prime} 25,9^{\prime \prime} \mathrm{N} \\
99^{\circ} 54^{\prime} 40,5^{\prime \prime} \mathrm{W}\end{array}$ & Acapulco & $\begin{array}{l}\text { Igneous fixed substrate, with variable size and many cracks, crevices } \\
\text { and holes. }\end{array}$ & Low \\
\hline \multicolumn{5}{|c|}{ Region costa grande } \\
\hline $\begin{array}{l}\text { Piedra de } \\
\text { Tlacoyunque }\end{array}$ & $\begin{array}{l}16^{\circ} 19^{\prime} 35,49^{\prime \prime} \mathrm{N} \\
98^{\circ} 34^{\prime} 12,65^{\prime \prime} \mathrm{W}\end{array}$ & $\begin{array}{l}\text { Tecpan de } \\
\text { Galeana }\end{array}$ & $\begin{array}{l}\text { Large blocks of intrusive igneous rocks, rough surface with folds, } \\
\text { fissures and cracks in a heterogeneous distribution. }\end{array}$ & High \\
\hline $\begin{array}{l}\text { Barra de Potosí } \\
\text { Expuesto }\end{array}$ & $\begin{array}{l}17^{\circ} 31^{\prime} 43,51^{\prime \prime} \mathrm{N} \\
101^{\circ} 27 ' 8,22^{\prime \prime} \mathrm{W}\end{array}$ & Petatlán & $\begin{array}{l}\text { Large metamorphic fixed rocks, hardly displaced by waves, with some } \\
\text { cracks and crevices, between a few smooth loose boulders. }\end{array}$ & High \\
\hline $\begin{array}{l}\text { Barra de Potosí } \\
\quad \text { Protegido }\end{array}$ & $\begin{array}{c}17^{\circ} 32^{\prime} 17,4^{\prime} \mathrm{N} \\
101^{\circ} 27^{\prime} 19,1^{\prime \prime} \mathrm{W}\end{array}$ & Petatlán & $\begin{array}{l}\text { Metamorphic rocks, smooth boulders around } 1 \mathrm{~m} \text { large with small } \\
\text { holes, some cracks and fissures, some displacement by wave's impact. }\end{array}$ & Media \\
\hline Troncones & $\begin{array}{c}17^{\circ} 47^{\prime} 35^{\prime \prime} \mathrm{N} \\
101^{\circ} 44^{\prime} 46,6^{\prime \prime} \mathrm{W}\end{array}$ & La Unión & $\begin{array}{l}\text { Sedimentary and volcano-sedimentary compact mounds, with abundant } \\
\text { cracks and crevices. }\end{array}$ & Media \\
\hline
\end{tabular}

Wave intensity $=$ W.I. Municipalyte $=$ MPIO.

\subsection{Fieldwork}

Sites were geo-referenced and their description based on [29] geological maps of the National Institute of Statistics, Geography and Informatics INEGI (Acapulco E14-11, 1:50,000) complemented with field observations. Wave intensity was classified according to the following criteria: 1) high, when the wave freely hits the substrate; 2) middle, when the wave impact on the substrate is hampered by smoothing or barriers; and 3) low, when the wave does not hit the substrate directly since the site is protected by different types of barriers. Each site was sampled on four occasions. The first sampling was conducted in March (drought season $<5 \mathrm{~mm}$ of rain), the second in June (start of the rainy season $<200 \mathrm{~mm}$ ), the third in September (end of the rainy season $>200 \mathrm{~mm}$ ) and the last in December (time of scarce rains $<10 \mathrm{~mm}$ in total). According to historical records [30] established for the period 1941 to 2005 the average annual rainfall was: January $2.9 \mathrm{~mm}$, in June $198.4 \mathrm{~mm}$, September 254.9 $\mathrm{mm}$, and December $6.2 \mathrm{~mm}$. Sampling was done at low tide on new moon days; the area sampled per site was of $20 \mathrm{~m}^{2}$, calculated by the method of species area [31]. The sampling unit consisted of a rectangle $2 \mathrm{~m}$ long $\times 1 \mathrm{~m}$ wide and delimited by a PVC frame. The starting point in the intertidal zone was randomly selected where the frame was set, with the sampling unit accommodated perpendicular to the coast and parallel to it by setting a rope $30 \mathrm{~m}$ in length. All mollusks within the sampling unit were collected, identified and counted. Once the first sampling unit was completed, the PVC frame was reset two meters further down the rope. This operation was repeated until the completion of $20 \mathrm{~m}^{2}$ for each site.

\subsection{Laboratory Work and Analysis}

The species that were not recognized in situ, were transferred to the laboratory for their processing to identify them by the use of proper literature [32], the nomenclature was updated [33-35]. The specimens were deposited in the "Colección de Moluscos de la Unidad Académica de Ecología Marina de la Universidad Autónoma de Guerrero." Species richness was measured in number of total species. The geographical distribution by site was analyzed based on the frequency of the species, and classified as: 1) wide distribution, when the species was present in at least seven sites; 2) regular distribution, when present on five or six sites; 3) limited distribution, when the species was present on three or four places; and 4) irregular distribution, when it was present between one and two sites out of the nine sites visited. The distribution by region and season of the species was analyzed on the basis of frequency of appearance. To analyze seasonal differences between the mean values of species 
richness, a single-factor ANOVA test was used, previously checking the homogeneity of variances by the Levene test [36]. To analyze the similarity of values on species richness per season, the hierarchical analysis (clusters) with the method of Euclidean squared distance test was used.

\section{Results}

\subsection{Species Richness}

Altogether 67,430 specimens were analyzed, and found a richness of 62 species in the rocky intertidal zone of the State of Guerrero, distributed in 50 Gastropoda species, nine Bivalvia and three for Polyplacophora. The highest overall species richness was at Barra de Potosi Protegido with 42 species and the lowest was at Piedra Tlacoyunque with 29. The highest species richness for the Class Gastropoda also was found in Barra de Potosi Protegido with 35 species, for Bivalvia was in Las Peñitas with eight species; and Polyplacophora presented equal dominance at three sites: Punta Maldonado, Barra de Potosi Protegida and Barra de Potosi Expuesta with three species on each site (Figure 2).

\subsection{Geographical Distribution}

Analyzing the distribution of species by coastal region, it was found that $46.8 \%$ of species were present in all three regions, $30.6 \%$ in two and $22.6 \%$ in one (Table 2). For the Class Gastropoda $46 \%$ of species were found in all

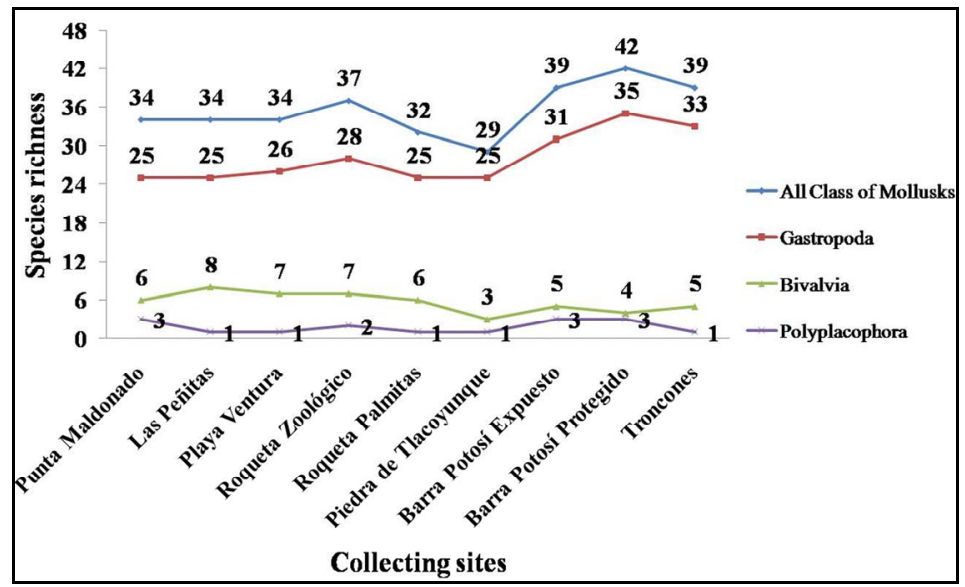

Figure 2. Mollusk species richness of nine sites in the rocky coast of the State of Guerrero.

Table 2. Species richness, frequency, site of collection, distributional type and seasonal distribution of the Class Gastropoda, Bivalvia and Polyplacophora in the intertidal rocky shores in the State of Guerrero, Mexico.

\begin{tabular}{|c|c|c|c|c|c|c|c|c|c|c|c|c|c|c|}
\hline \multirow{2}{*}{$\begin{array}{c}\text { Families/Species } \\
\text { Gastropoda }\end{array}$} & \multirow[t]{2}{*}{ SFD } & \multicolumn{3}{|c|}{ C.CHIC. } & \multicolumn{3}{|c|}{ ACA. } & \multicolumn{3}{|c|}{ C. GRANDE } & \multicolumn{4}{|c|}{ DS } \\
\hline & & 1 & 2 & 3 & 4 & 5 & 6 & 7 & 8 & 9 & 1 & 2 & 3 & 4 \\
\hline \multicolumn{15}{|l|}{ LOTTIIDAE Gray, 1840) } \\
\hline Lottia acutapex (Berry, 1960) & $\mathbf{R}$ & - & - & - & - & & & - & & & - & - & - & - \\
\hline Lottia mitella (Menke, 1847) & $\mathbf{W}$ & - & - & - & & & - & - & - & - & - & - & - & - \\
\hline Lottia mesoleuca (Menke, 1851) & $\mathbf{W}$ & & & & - & & & & & & & - & & \\
\hline Tectura fascicularis (Menke, 1851) & $\mathbf{W}$ & - & - & - & - & - & - & - & - & & - & - & - & - \\
\hline Tectura filosa (Carpenter, 1865) & $\mathbf{W}$ & - & - & - & & & - & - & - & - & - & - & - & - \\
\hline \multicolumn{15}{|l|}{ FISSURELLIDAE } \\
\hline Fissurella (C.) asperella (Sowerby, 1835) & W & & - & - & - & & - & - & - & - & - & - & - & - \\
\hline Fissurella (C.) gemmata (Menke, 1847) & $\mathbf{W}$ & - & - & - & - & - & - & - & - & & - & - & - & - \\
\hline Fissurella (C.) nigrocincta (Carpenter, 1856) & $\mathbf{W}$ & - & - & - & - & - & - & - & - & & - & - & - & - \\
\hline Fissurella (C.) obscura (Sowerby, 1835) & $\mathbf{W}$ & - & . & - & - & & & - & - & - & - & - & - & - \\
\hline
\end{tabular}


TURBINIDAE

Astraea (U.) buschii (Philippi, 1844)

Eulithidium phasianella (Philippi, 1849)

TROCHIDAE

Tegula (A.) globulus (Carpenter, 1857)

Tegula (A.) maculostriata (C. B. Adams, 1845)

\section{NERITIDAE}

Nerita (R.) scabricosta (Lamark, 1822)

Nerita (T.) funiculate (Menke, 1851)

LITTORINIDAE

Nodilittorina (N.) aspera (Philippi, 1846)

Nodilittorina modesta (Philippi, 1846)

\section{VERMETIDAE}

Petaloconchus (P.) complicates (Dall, 1908)

Petaloconchus macroprhacma (Carpenter, 1857)

CERITHIDAE

Cerithium (T.) menkei (Carpenter, 1857)

Liocerithium judithae (Keen, 1971)

\section{PLANAXIDAE}

Planaxis obsoletus (Menke, 1851)

HIPPONICIDAE

Hipponix A. panamensis (C. B. Adams, 1852)

Pilosabia pilosa (Deshayes, 1832)

\section{CALYPTRAIDAE}

Crucibulum (C.) monticulus (Berry, 1969)

Crepidula excavata (Broderip, 1834)

Crucibulum (C.) scutellatum (Wood, 1828)

$$
\text { MURICIDAE }
$$

Mancinella speciosa (Valenciennes, 1832)

Mancinella triangularis (Blainville, 1832)

Stramonita biserialis (Blainville, 1832)

Acanthais brevidentata (Wood, 1828)

Thais (T.) kiosquiformis (Duclos, 1832)

Vasula (V.) melones (Dulcos, 1832)

Plicopurpura columellaris (Lamark, 1822)

Plicopurpura pansa (Gould, 1853)

\section{BUCCINIDAE}

Cantharus (P.) sanguinolentus (Duclos, 1833)

\section{FASCIOLARIIDAE}

Leucozonia cerata (Wood, 1828)

Opeatostoma pseudodon (Burrow, 1815)

W

L

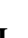

W

W

I

I

L

$$
\text { L }
$$$$
\mathbf{W}
$$$$
\text { W }
$$

W

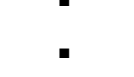

I

I

L

\section{I}

L

$$
\text { I }
$$
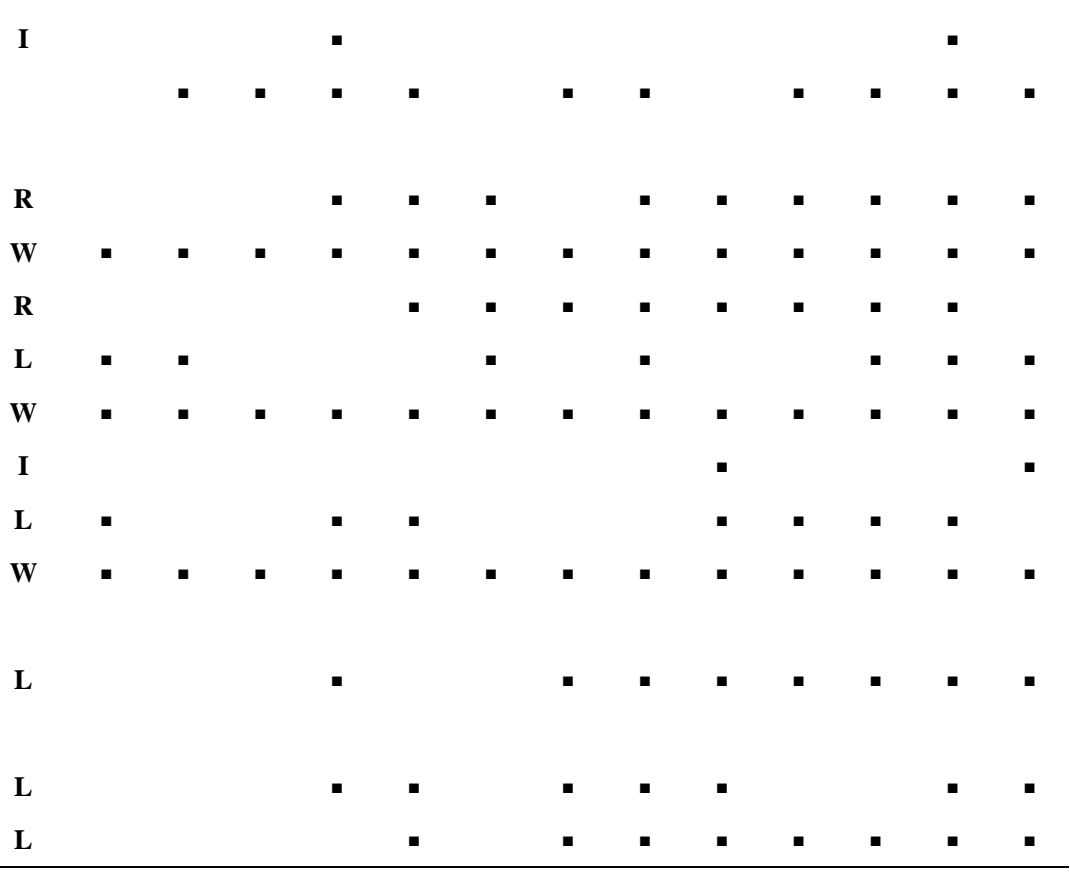


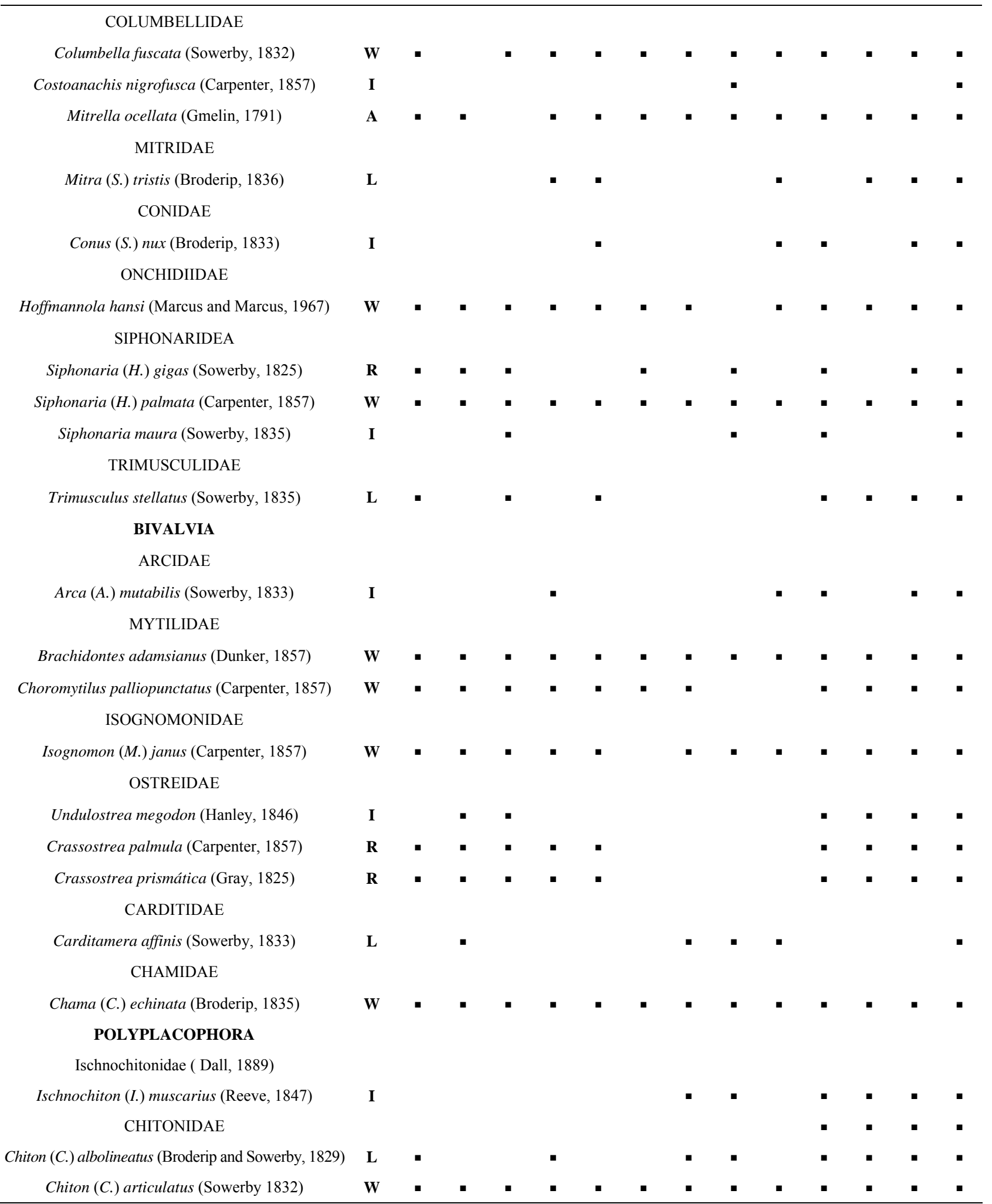

Regions: C.CHIC. $=$ Costa Chica; ACA. $=$ Acapulco; C. GRANDE $=$ Costa Grande; DS = Distribution per season; Sites: $1=$ Punta Maldonado; $2=$ Las Peñitas; $3=$ Playa Ventura; 4 = Roqueta Zoológico; $5=$ Roqueta Palmitas; $6=$ Piedra de Tlacoyunque; 7 = Barra Potosí Expuesta; $8=$ Barra Potosí Protegida; $9=$ Troncones; Species present $=\mathbf{m}$. Species Frequency of Distribution: $\mathrm{W}=$ Wide; $\mathrm{R}=$ Regular; $\mathrm{L}=$ Limited; $\mathrm{I}=$ Irregular; Seasons: $1=$ Start of the rainy season; $2=$ End of the rainy season; 3 = Time of scarce rains; 4 = Drought season. 
three regions, $28 \%$ in two and $26 \%$ in one. Bivalvia presented $44.44 \%$ in three regions, the same percentage in two and $11.11 \%$ at one. Polyplacophora had $66.66 \%$ of species found in three regions and $33.3 \%$ in one. When examining the distribution of species by collection site, it was found that for Gastropoda $38.7 \%$ of the species had wide distribution, $14.5 \%$ regular distribution, $22.6 \% \mathrm{lim}$ ited and $24.2 \%$ irregular.

Bivalvia had $44.4 \%$ with wide distribution, $22.22 \%$ with regular distribution, $11.1 \%$ limited and $22.22 \%$ irregular. On Polyplacophora $33.33 \%$ of the species presented wide distribution, $33.33 \%$ limited and $33.33 \%$ irregular.

\subsection{Changes in Species Richness as a Result of Rains}

Species richness per season was 50 species at the start of the rainy season, 49 by the end of the rainy season, 50 in time of scarce rains and 52 species in drought season. Also by comparing richness values for each Class separately, there were minimal variations (Table 3).

Considering the species distribution per season, it was found that $62.9 \%$ of all species were present during all four seasons (Figures 3(a) and (b)), 14.5\% were present in three, $8.1 \%$ in two and $14.5 \%$ in one, (Table 2).

Examining the distribution of species per season for each Class, it was found that Gastropoda had 58\% of species in all seasons, Bivalvia $77.8 \%$ and Polyplacophora $100 \%$ (Figure 4). Examining the distribution of species per season for each Class, it was found that Gastropoda had $58 \%$ of species in all seasons, Bivalvia $77.8 \%$ and Polyplacophora 100\% (Figure 4).

We found an average of 23.36 species per season ( $\min$ 14 , $\max 36$, SD 4.35). The average species richness at the beginning of rain season was $23.88(\min 19, \max 30$, SD 3.37), end of the rainy season in $21.55(\min 14$, max. 25, SD 4.19), in time of scarce rains $23.11(\min 16, \max$ 32 , SD 4.8) for drought season 24.88 ( $\min 20$, $\max 36$, SD 4.9) (Table 4). The average species richness during different seasons did not show statistically significant

Table 3. Values of species richness by season and class of mollusk on the rocky coast of the State of Guerrero, Mexico.

\begin{tabular}{ccccc}
\hline Season & Gas (n) & BIV (n) & Poly (n) & T. \\
\hline Start of the rainy season. & 39 & 8 & 3 & 50 \\
End of the rainy season. & 39 & 7 & 3 & 49 \\
Time of scarce rains. & 39 & 8 & 3 & 50 \\
Drought season. & 41 & 8 & 3 & 52 \\
\hline
\end{tabular}

GAS $=$ Gastropoda BIV $=$ Bivalvia; POLY $=$ Polyplacophora T.$=$ Total $; \mathrm{N}=$ species richness found by class.

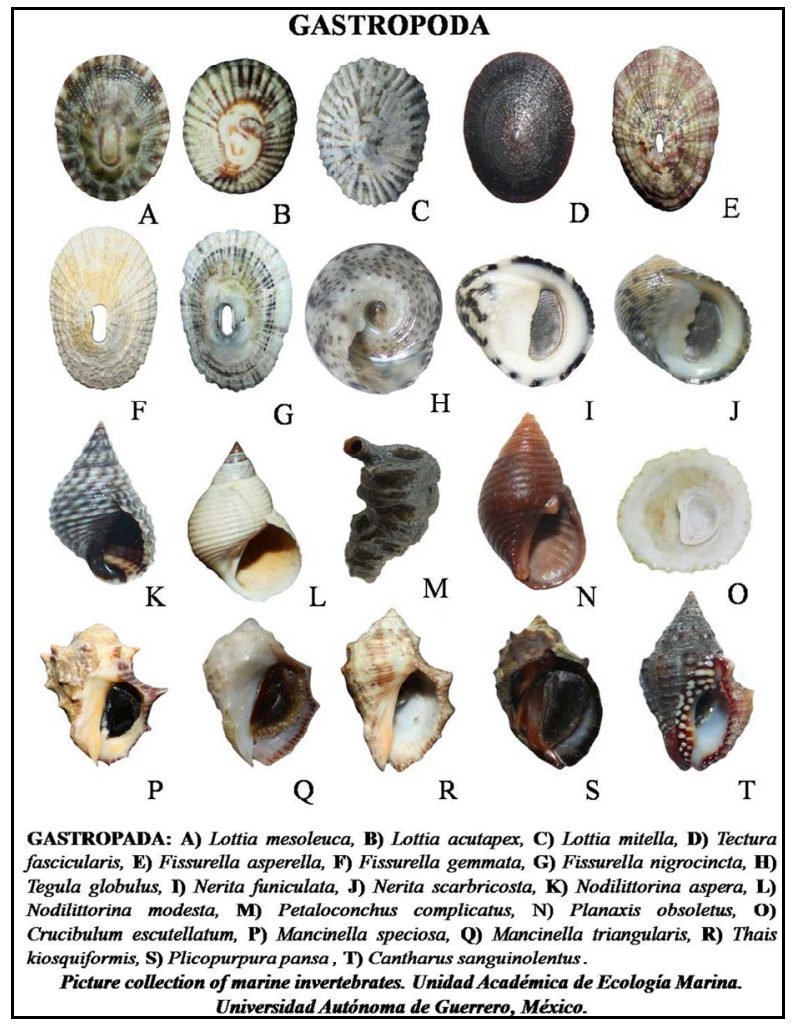

(a)

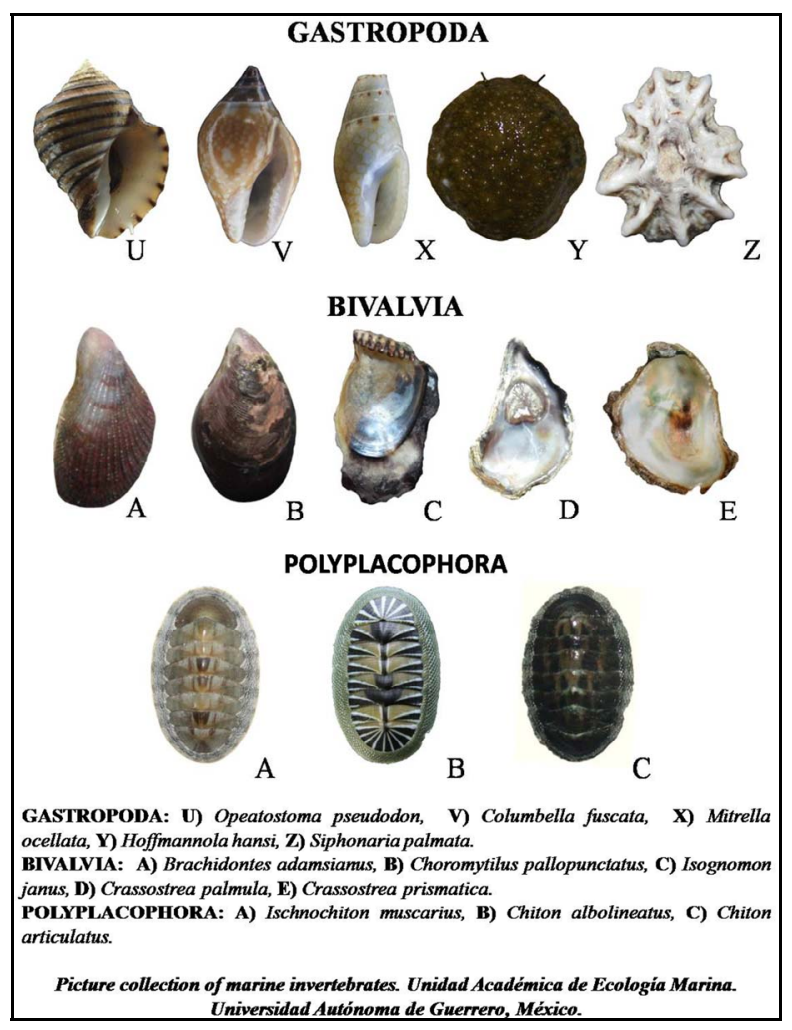

(b)

Figure 3. Species present in all four seasons with wide distribution. 


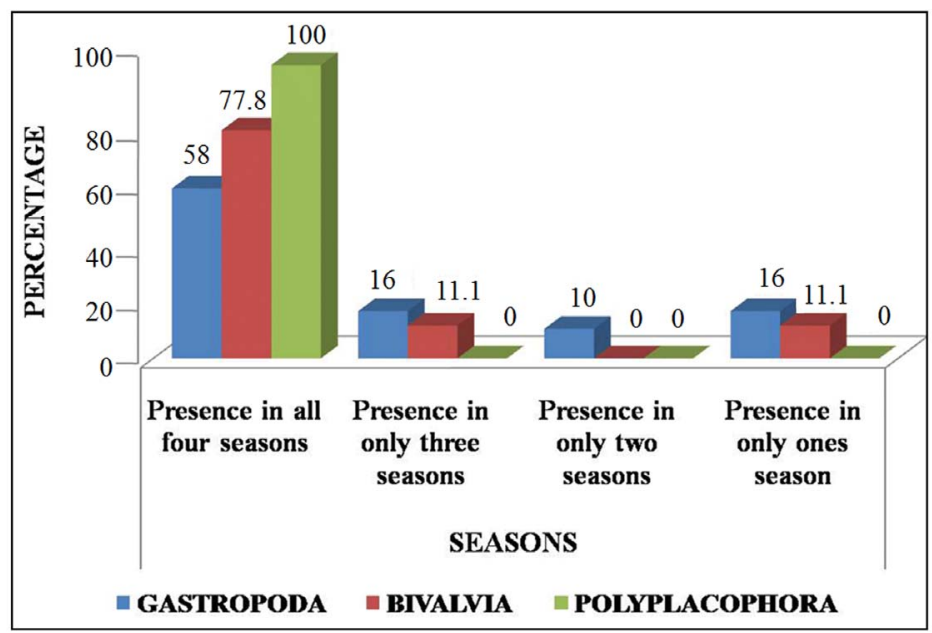

Figure 4. Species percentage of Gastropoda, Bivalvia and Polyplacophora, according to their seasonal distribution in the rocky coast of the State of Guerrero, Mexico.

Table 4. Species richness value per site and per rainy season in the rocky coast of the Staste of Guerrero, Mexico.

\begin{tabular}{ccccc}
\hline Site & $\begin{array}{c}\text { Start of the rainy season } \\
(\mathrm{n})\end{array}$ & $\begin{array}{c}\text { End of the rainy season } \\
(\mathrm{n})\end{array}$ & Time of scarce rains (n) & Drought season (n) \\
\hline Punta Maldonado & 24 & 25 & 24 & 20 \\
Las Peñitas & 19 & 25 & 23 & 26 \\
Playa Ventura & 27 & 23 & 22 & 25 \\
Roqueta Zoológico & 22 & 25 & 26 & 21 \\
Roqueta Palmitas & 22 & 16 & 17 & 22 \\
Piedra de Tlacoyunque & 21 & 14 & 22 & 21 \\
Barra Potosí Expuesto & 26 & 23 & 32 & 26 \\
Barra Potosí Protegido & 30 & 24 & 26 & 36 \\
Troncones & 24 & 19 & 23.11 & 27 \\
AVERAGE & 23.88 & 21.55 & 4.83 & 4.91 \\
Standar deviation & 3.37 & 4.18 & & 26 \\
\hline
\end{tabular}

(n) $=$ species richness found by season.

differences either (ANOVA, $\mathrm{P}=0.436$ ). For Gastropoda (ANOVA, $\mathrm{P}=0.647$ ), Bivalvia (ANOVA, $\mathrm{P}=0.862$ ) and Polyplacophora (ANOVA, $\mathrm{P}=0.714$ ) mean values of species richness for different seasons did not show statisticcally significant differences either.

Furthermore, hierarchical cluster test applied to the values of species richness for the four seasons produced the formation of two groups: The first consisted of the values of species richness in drought seasons and start of the rainy season; these values had higher relative similarity. The second group was formed by the values of species richness of the end of the rainy season and the time of scarce rains (Figure 5).

The hierarchy Class species richness analysis for Gastropoda established a group of greater similarity with drought season and the time of scarce rains one. A second group was formed with the values of species richness at the start of the rainy season plus the first group formed (Figure 6). It is also noted that the value of species richness of the end of rainy season did not show relative similarity with the two groups formed. For Bivalvia, the hierarchical analysis determined the formation of two groups with approximately the same similarity. The first group was established by the values of species richness with the end of the rainy season plus the drought season period. A second group was formed by the relative similarity of the values of species richness in the start of the rainy season and the time of scarce rains (Figure 7).

On Polyplacophora the species richness values in the different seasons analyzed, were very homogeneous and 


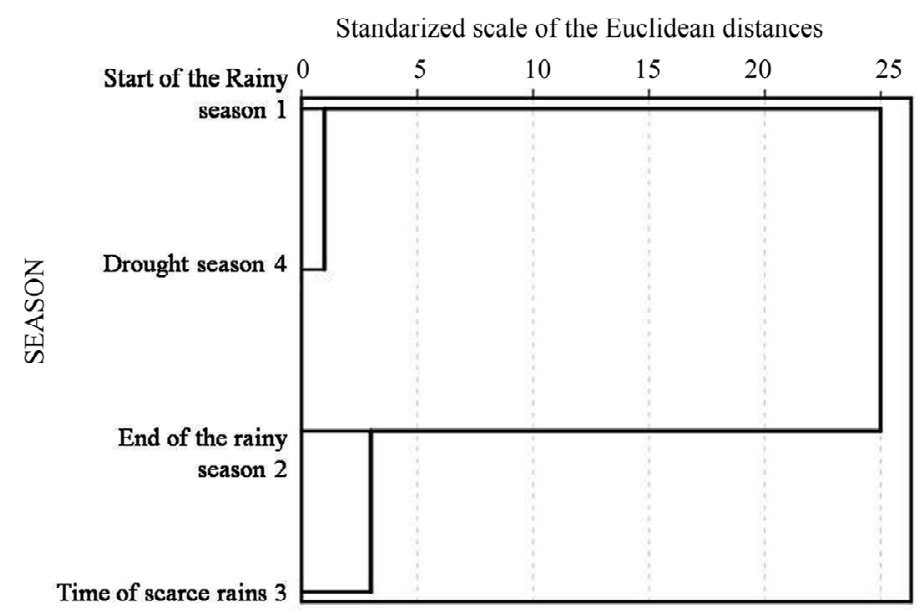

Figure 5. Richness values dendrogram of Class Gastropoda, Bivalvia and Polyplacophora by rainy season on the rocky coast of the State of Guerrero, Mexico, using a halflink between groups.

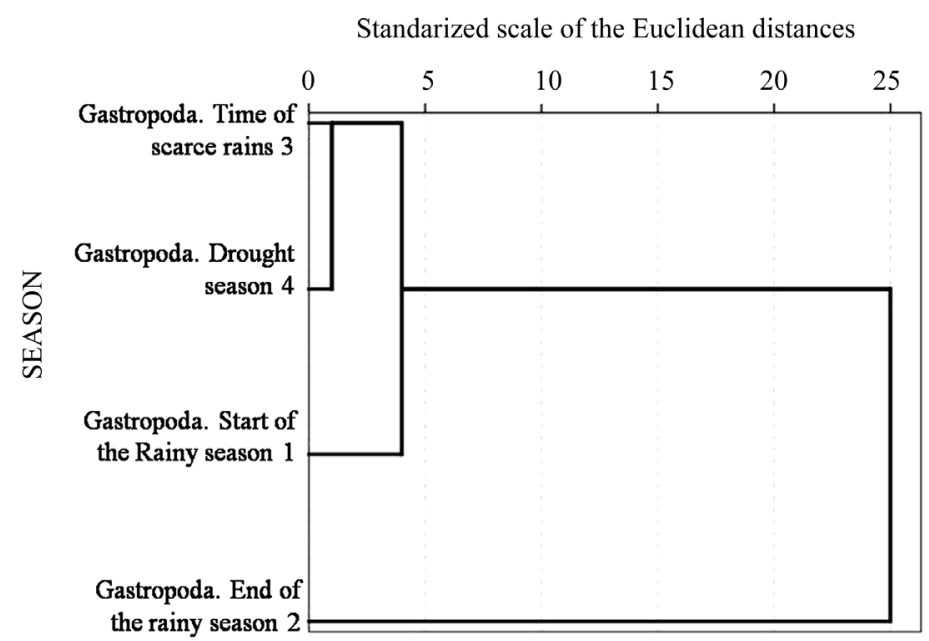

Figure 6. Richness values dendrogram of Class Gastropoda by rainy season on the rocky coast of the State of Guerrero, Mexico, using a halflink between groups.

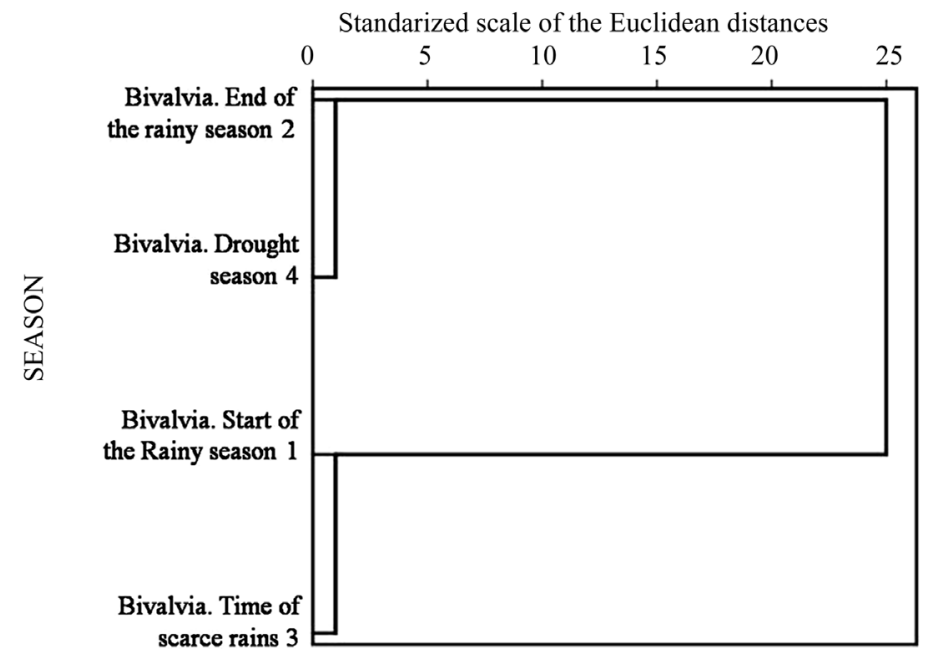

Figure 7. Richness values dendrogram of Class Bivalvia by rainy season on the rocky coast of the State of Guerrero, Mexico, using a half link between groups. 
were not possible to see the formation of groups using the cluster test.

\section{Discussion and Conclusion}

\subsection{Species Richness}

Species richness found was higher than previously reported in works that had deployed the same field methodology [16,23,24], Also species richness was higher than previously reported [22], even when the collecting methodology was different. For the Acapulco region [18, 19], previous species richness results were lower than here reported. The high species richness found, corresponds to that expected in a tropical area characterized by low variations in sea water temperature, it also happens that the substrate is complex, and it has rocks that vary greatly in dimensions, from gravel to large blocks, creating diverse habitats where many organisms can be protected and become established. Besides the sampled sites were representative of the different types of substrates present in the intertidal rocky coast of the State of Guerrero. The species richness proportion for each Class was similar to that previously reported for the State of Guerrero, except on $[18,19]$ where Polyplacophora had higher species richness than Bivalvia. This difference could be caused by the type of environment, which favors chitons and is less conducive for Bivalves by its instability or harshness. It also coincided with beaches [7] composed of large physically stable boulders, more so than those beaches composed of small rocks or loose rock fragments, so it points to a direct correlation in this type of beaches between habitat stability and species richness. For Costa Rica [5], a richness of 42 species was reported for habitat consisting of pebble substrate compared to 25 species on the site with firm cliff substrate. Highest species richness showed up on Barra de Potosi Protegido, a place where waves had medium intensity, and the substrate was somewhat unstable when the waves hit, formed by smooth boulders and scarce presence of cracks and fissures, this arrangement generates many interspaces between stones and rocks where mollusks can be located. There are two sites as second in species richness that differ from the above mentioned, one of them Barra de Potosi Expuesto, with high intensity waves, presents a substrate composed by a combination of rocky cliffs with cracks and fissures, large boulders stable to wave impact; the other site, Troncones, has medium wave intensity and the substrate composed by volcanic sedimentary rocks, with compact mounds and a great amount of fissures and cracks, all of which provides potential refuge to many organisms. On the other hand, the lowest species richness was presented at Piedra de Tlacoyunque, a zone with high intensity waves and stable substrate, formed of large blocks with folds, fissures and cracks irregularly distributed.

\subsection{Geographical Distribution}

Almost half of the species found in the rocky intertidal zone of the State of Guerrero were present in all three regions; these species [6] were considered as generalists, while the rest were confined to one or two regions, indicating that almost half of the species present at the community, is made up of specialist species, those with a higher level of adaptation. By applying distributional analysis by site, the same results were obtained indicating that most species showed broad distribution, associated with those which had regular distribution constituted more than $50 \%$. These were considered to be broadly distributed and generalist, present in all the types of habitat analyzed. Almost the same percentage of species was found associated with fewer sites, indicating that these species can be considered as specialists. A comparative study of intertidal tropical and temperate species [6] had indicated that tropical Gastropoda were found in fewer habitats and were more specialized, consistent with the findings in this work. On the analysis of geographical distribution by region and site, at the State of Guerrero those species that have high spatial representation and are generalists, contribute with the greatest representation. On the other hand, species with spatial representation restricted to a region or a few sites, being only slightly less than the proportion of generalists, the difference was not significant. The balance between the number of species of large spatial representation and those with limited representation is benefited from the variety of substrates and the differences in wave intensity found.

\subsection{Changes in Species Richness as a Result of the Rains}

The analysis of mollusk species richness in the different rain seasons shows roughly constant values; this implies that the difference in the amount of rain per season does not change the number of species present in the rocky intertidal ecosystem, and supports the idea that species richness is quantitatively constant throughout the year. The same analysis done for each Class, had exhibited the same behavior. Regarding species distribution per rainy season, Gastropoda had the lower amount of species in all the four seasons, which means that major changes in species richness as result of the rains were observed in this Class. The proportion of Bivalvia species present in the four seasons was higher, so this Class supports fewer changes under the effect of the rains. No changes in species richness were observed for Polyplacophora, since the $100 \%$ of its species were present in all four seasons. 
The fact that the species of Polyplacophora were present in all seasons could be attributed to the greater adaptability of them to this kind of environment, to which they are well adapted by having the body structured as articulated plates, belt, large muscular foot, flattened body and oval shape, also are not displaced by the increase in algal cover grown by rains, since it was common to find them seeking refuge among algae into the cavities and crevices. The Bivalvia appeared as the second group present in all seasons. This is understandable because most of its species remain fixed to the substrate and can hardly be displaced by algae growth. The biggest change in species richness as a result of rainfall was observed in Gastropoda. The characteristics of this Class such as smaller muscular foot compared to the chitons, the varied shape of its shell and the variety of feeding habits, caused them to have a lesser degree of adaptability to the conditions during rain at the intertidal. This coincides with preliminary findings [19] concerning better adaptation to these sorts of conditions by Class and species of Polyplacophora and Bivalvia, and the one with lower adaption, Gastropoda. Therefore based on species composition, which report Class Polyplacophora at the highest number of dominant species by percentage, making clear that members of this Class are more efficient to withstand the rocky intertidal harsh conditions. Bivalvia show the second percentage in dominant species, they are fixed with byssus or cemented to the substrate, where they were the major dominant species; and finally the Gastropoda, among whose dominant species are those characterized by having shielded or ear shaped shells. By comparing the species richness analyzed by season, the averaged values for the three Class altogether, there were no statistically significant differences observed. The same happened when analyzed for each Class. No quantitative change in species richness was influenced by rainfall on an annual cycle, and as has been stated [3], the species stability indicates that the environment is far from suffering processes of degradation or deterioration caused by rain. Applying cluster analysis for species richness for each season to the three Classes altogether, the formation of two groups was found, the first group made up by the species richness of two sequential seasons, the drought season and the start of the rainy season, associated to the gradual increase in precipitation. The second group was formed with species richness of the start of the rainy season and time of scarce rains, which happened to be sequential at the same time, the formation of this group was associated with the decrease in precipitation. The formation of groups reflects the amount of rainfall during different seasons. It was noted that the start of the rainy season and the end of the rainy season, were not pooled, assuming that the intensity of rainfall causes significant alterations of habitat and thus the species richness changes, in [7] a direct correlation between the habitat stability and species richness. By analyzing species richness per season for each of the Classes by cluster analysis, it was found that, for Class Gastropoda groups were formed corresponding to the amount of precipitation, the greater similarity group made up by the two seasons of lower amount of rain (drought season and time of scarce rains), and followed by a second group that had lesser similarity and presented an increment in the amount of precipitation, which includes the previous group plus the group formed at the start of rainy season (time of scarce rainsdrought season - start of the rainy season). Species richness of rainy season did not join or form any group. This could be related to the significant habitat changes due to higher amount of rainfall, the increment of wave intensity on the substrate, the considerable increment of algae cover overlying cracks and cavities, which in turn induce the species of Gastropoda to move or seek to be accommodated in other type of habitat. In agreement [8] to rocky shore communities that are affected by waves and this in turn determines the growth of algae, and subsequently animals, causing large differences in the distribution of coastal organisms from one place to another because of geographical, geological and climatic conditions. Moreover the adaptation of Gastropoda to the rocky intertidal zone shows that, because it has fewer amount of families that has shells with shielded shape or ear type forms, which can stand quite well the impact of the waves; While a large number of families present shells with spiral or coiled form that could be at disadvantage in the middle of the intertidal. When comparing two beaches, [4] a protected one and another exposed, its biota was probably distributed according to their abilities to withstand wave and air conditions exposure. Bivalvia Class formed two groups, one composed of species present during drought season and end of the rainy season; and another group formed by the one at the start of the rainy season and the one at time of scarce season. These groups do not responded to gradual changes in the amount of rain. It is particularly important to mention that, the members of the Class Bivalvia are essentially sessile, so provably they can hardly be displaced by algae or dislodged by the waves, so it could not be concluded that there is a change in the species richness of bivalves influenced by the amount of precipitation.

\section{Final Conclusions}

The mollusk community associated with the intertidal rocky substrate at the State of Guerrero is very diverse, and by studying species richness change due to rain does not produced quantitative effect, and presented similar proportions of species with large spatial representation 
(generalist) and those with restricted representation (specialists). However, the analysis for each Class showed significant differences, mainly for Gastropoda, which had the highest proportion of species with restricted spatial representation, forming groups in species richness that respond to changes in the amount of rainfall for each season studied. This sort of behavioral trait for Gastropoda with species sensible to the amount of rain could lead to rate some of them as possible "bioindicators" for changes in the environment, and is worth to keep for closer look on them for further analysis.

\section{Acknowledgements}

Thanks are due to the Faculty Improvement Program (Programa de Mejoramiento del Profesorado PROMEP) by the Secretary of Public Education (Secretaria de Educación Publica SEP)/“Subsecretaría de Educación Superior" SES, Mexico, that funded this project as part of the support for the incorporation of former fellow students, authors of this work.

Thanks are due to Arcadio Valdes Gonzales for overseeing, reviewing and translation services, and to Kit Stowell for correcting and improving the final manuscript.

\section{REFERENCES}

[1] E. Medianero, M. Paniagua and G. Castaño-Meneses, “Comparación Temporal de la Riqueza y Composición de Insectos Inductores de Agallas en el Dosel de un Bosque Tropical," Revista Mexicana de Biodiversidad, Vol. 81, No. 2010, pp. 465-472.

[2] M. G. Chapman, “A Comparative Study of Differences among Species and Patches of Habitat on Movements of Three Species of Intertidal Gastropods," Journal of Experimental Marine Biology and Ecology, Vol. 244, No. 2, 2000, pp. 181-201. doi:10.1016/S0022-0981(99)00140-9

[3] A. E. Magurran, "Diversidad ecolÓgica y su Medición," Ediciones Vedra, 1989.

[4] J. R. Lewis, "The Ecology of Rocky Shores," The English Universities Press Ltd., London, 1964.

[5] T. M. Spight, "Censuses of Rocky Shore Prosobranchs from Washington and Costa Rica," The Veliger, Vol. 18, No. 3, 1976, pp. 309-317.

[6] T. M. Spight, "Diversity of Shallow-Water Gastropods Communities on Temperate and Tropical Beaches," American Naturalist, Vol. 111, No. 982, 1977, pp. 1077-1097. doi:10.1086/283239

[7] R. R. Brusca, "Common Intertidial Invertebrates of the Gulf of California," The University of Arizona Press, Tucson, 1980.

[8] R. V. Tait and F. S. Dipper, "Elements of Marine Ecology," Butterworth-Heinemann, Oxford, 1998.

[9] C. F. Román, F. M. Cruz and A. L. Ibáñez, "Observaciones Ecológicas de Los Moluscos de la Zona Intermareal de la
bahÍa de Chamela, Jalisco, México," Anales Instituto de Biología UNAM Serie: Zoología, Vol. 62, No. 1, 1991, pp. 17-31.

[10] M. C. Esqueda, E. Ríos-Jara, J. E. Michel-Morfín and V. Landa-Jaime, "The Vertical Distribution and Abundance of Gastropods and Bivalves from Rocky Beaches of Cuastecomate Bay, Jalisco," Revista de Biología Tropical, Vol. 48, No. 4, 2000, pp. 765-775.

[11] F. J. González, O. E. Holguín and G. de la Cruz, "Variación Espacio Temporal de Algunos Macroinvertebrados (Gastropoda, Bivalvia, Equinodermata) de Fondos Someros del Archipiélago Espíritu Santo, Baja California, Sur, México," Ciencias Marinas, Vol. 32 No. 1, 2006, pp. 33-44.

[12] O. E. Holguín, H. Wright and E. F. Pico, "Moluscos Intermareales y de Fondos Someros de la Bahía de Loreto, B.C.S., México," Oceanides, Vol. 15, No. 2, 2000 pp. 91115.

[13] E. Villalpando Canchola, "Diversidad y Zonación de Moluscos de Facie Rocosa Isla Roqueta, Acapulco, Guerrero," Tesis Profesional Inédita, Universidad Nacional Autónoma de México, Mexico City, 1986.

[14] V. H. Delgado Blas, "Estudio Sistemático y Aspectos Ecológicos de gasterópodos de la facie Rocosa de la Bahía de Acapulco, Guerrero, México," Tesis Profesional Inédita, Escuela Superior de Ecología Marina, Universidad Autónoma de Guerrero, Mexico City, 1989.

[15] J. A. García López, "Fauna Malacológica de Acompañamiento del Caracol Purpura pansa (Gould, 1853) en la Zona Mesolitoral de la Isla La Roqueta, Acapulco, Guerrero, México,” Tesis Profesional inédita, Escuela Superior de Ecología Marina, Universidad Autónoma de Guerrero, Mexico City, 1994.

[16] P. Flores-Rodríguez, R. Flores-Garza and S. García-Ibáñez, "Riqueza y Diversidad de la Malacofauna del Mesolitoral Rocoso de la Isla de La Roqueta, Acapulco, Guerrero, México," Revista de Investigación Científica, Vol. 11, 2003, pp. 5-14.

[17] A. Valdés-González, P. Flores-Rodríguez, R. Flores-Garza and S. García-Ibáñez, "Molluscan Communities of Rocky Intertidal Zone at Two Sites with Different Wave Action on Isla la Roqueta, Acapulco, Guerrero, México,” Journal of Shellfish Research, Vol. 23, No. 3, 2004, pp. 875-880.

[18] R. Flores-Garza, C. Torreblanca-Ramírez, P. Flores Rodríguez, S. García-Ibáñez and L. Galeana-Rebolledo, "Riqueza y Análisis de la Comunidad Malacológica en el Mesolitoral Rocoso la Playa Tlacopanocha, Acapulco, Guerrero," In: L. J. Rangel, J. Gamboa, S. L. Arriaga and W. M. Contreras, Eds., Perspectivas en Malacología Mexicana, Universidad Juárez Autónoma de Tabasco, Villahermosa, 2010, pp. 125-138.

[19] R. Flores-Garza, C. Torreblanca-Ramírez, P. Flores-Rodríguez, S. García-Ibáñez, L. Galeana-Rebolledo, A. ValdésGonzález and A. A. Rojas-Herrera, "Mollusc Community from a Rocky Intertidal Zone in Acapulco, México," Biodiversity, Vol. 12, No. 3, 2011, pp. 144-153. doi:10.1080/14888386.2011.625520

[20] R. Flores-Garza, S. García-Ibáñez, P. Flores-Rodríguez, C. Torreblanca-Ramírez, L. Galeana-Rebolledo, A. Valdés- 
González and A. Suástegui-Zárate, "Commercially Important Marine Mollusks for Human Consumption in Acapulco, México," Natural Resources, Vol. 3, No. 1, 2012, pp. 11-17. doi:10.4236/nr.2012.31003

http://www.SciRP.org/journal/nr

[21] F. Barba-Marino, P. Flores-Rodríguez, R. Flores-Garza, S. García-Ibáñez and D. G. Arana-Salvador,"Biodiversidad y Zonificación de la Comunidad de Moluscos, Que Habita el Sustrato Rocoso en dos Sitios con Distinta Acción del Oleaje, en la Isla La Roqueta, Acapulco, Guerrero, México,” In: L. J. Rangel, J. Gamboa, S. L. Arriaga and W. M. Contreras, Eds., Perspectivas en Malacología Mexicana, Universidad Juárez Autónoma de Tabasco, Villahermosa, 2010, pp. 21-43.

[22] M. S. Salcedo, G. Green, A. Gamboa and P. Gómez, "Inventario de Macroalgas y Macroinvertebrados Bénticos, Presentes en áreas Rocosas de la Región de Zihuatanejo, Guerrero, México," Anales del Instituto Ciencias del Mar y Limnologia, Vol. 15, No. 1, 1988, pp. 73-96.

[23] R. Flores-Garza, P. Flores-Rodríguez, S. García-Ibáñez and A. Valdés-González, "Demografía del Caracol Plicopurpura pansa (Neotaenioglossa: Muricidae) y Constitución de la Comunidad Malacológica Asociada en Guerrero, México," Revista de Biológica Tropical, Vol. 55, No. 3-4, 2007, pp. 867-878.

[24] P. Flores-Rodríguez, R. Flores-Garza, S. García-Ibáñez and A. Valdés González, "Variación en la Diversidad Malacológica del Mesolitoral Rocoso en Playa Troncones, La Unión, Guerrero, México," Revista Mexicana de Biodiversidad, Vol. 78, No. 2, 2007, pp. 33S-40S.

[25] A. Carranza-Edwards, M. Gutiérrez-Estrada and R. Rodríguez-Torres, "Unidades Morfo-Tectónicas Continentales de las Costas Mexicanas," Anales del Instituto de Ciencias Del Mar y Limnología, Vol. 2, No. 1, 1975, pp. 81-88.
[26] E. G. De La Lanza, "Oceanografía de los Mares Mexicanos," 1991.

[27] Secretaría de Marina, "Estudio Geográfico de la Región de Acapulco, Guerrero, México," Dirección General de Oceanografía, México City, 1977.

[28] “Secretaría de Comunicaciones y Transportes 2011," Subdirección de Meteorología, Dirección General de Marina Mercante, 2011. http://www.sct.gob.mx/puertos-y-marina-mercante/

[29] A. Mottana, R. Crespiand G. Liborio, "Guía de minerales y rocas,” Editorial Grijalbo, Barcelona, 1980.

[30] CONAGUA, "Precipitación Media Anual 1941-2005," 2010. http://smn.cna.gob.mx/index.php?option=com_content\&v iew $=$ article $\&$ id $=12 \&$ Itemid $=77$

[31] J. E. Brower, J. H. Zarand C. N. Von Ende, "Field and Laboratory Methods for General Ecology," WCB/McGrawHill Companies, Boston, 1998.

[32] A. M. Keen, "Sea Shells of Tropical West America," Stanford University Press, Stanford, 1971.

[33] C. Skoglund, "Panamic Province Molluscan Literature 1971 through 2000," Bibalvia," The Festivus, Vol. 32, 2001, pp. 1-119.

[34] C. Skoglund, "Panamic Province Molluscan Literature 1971 through 2000, II Polyplacophora," The Festivus, Vol. 32, 2001, pp. 1-20.

[35] C. Skoglund, "Panamic Province Molluscan Literature Additions and Changes from 1971 through 2001, III Gastropoda," The Festivus, Vol. 33, 2002, pp. 1-286.

[36] W. W. Daniel, "Biodestadística," Limusa-Wiley, México, 2004. 